\title{
RANCANG BANGUN SISTEM KONTROL DAN MONITORING LAMPU OTOMATIS MENGGUNAKAN ARDUINO DENGAN METODE FUZZY LOGIC BERBASIS ANDROID (Studi Kasus Koridor Lantai 1 dan 2 Fakultas Ilmu Komputer)
}

\author{
Rahmat Ramdhoni ${ }^{1}$, Sugeng Supriyadi ${ }^{2}$, Nunu Nugraha ${ }^{3}$ \\ Fakultas Ilmu Komputer Universitas Kuningan \\ Jl. Cut Nyak Dien No.36 A, Kel. Cijoho Kuningan 45513 \\ rahmatramdhoni@gmail.com ${ }^{1}$,nunu.nugraha@ uniku.ac.id ${ }^{2,}$ sugeng@uniku.ac.id ${ }^{3}$
}

\begin{abstract}
Abstrak - Seiring kemajuan teknologi yang semakin pesat diberbagai bidang, termasuk bidang elektronika kebutuhan akan kemudahan dan kenyamanan dalam pengontrolan alat-alat listrik sangat penting, khususnya pengontrolan dan monitoring lampu Selama ini masyarakat dapat mengontrol perangkat listrik hanya dengan saklar yang terhubung melalui kabel. Maka dibutuhkan suatu sistem kontrol dan monitoring lampu secara otomatis, salah satu sistem yang dibuat yaitu dengan menggunakan mikrokontroller. Dari beberapa permasalahan yang teridentifikasi salah satunya adalah sistem yang sedang berjalan masih belum efektif karena dalam pengontrolan lampu masih dilakukan secara manual serta belum terjadwal kapan lampu itu seharusnya menyala. Metode Pengembangan perangkat lunak yang digunakan adalah metode Rational Unified Process (RUP) dengan menggunakan perancangan Unified Modeling Language (UML) diantaranya use case diagram, skenario, activity diagram, class diagram dan sequence diagram. Sedangkan metode penyelesaian masalah yang digunakan adalah metode Fuzzy Logic. Sistem pengontrolan dan monitoring lampu yang dibangun dengan menerapkan metode fuzzy logic untuk mengektifkan pengontrolan dan monioring lampu secara otomatis. Sistem dapat diterapkan pada objek penelitian dan membantu dalam proses pengontrolan dan monitoring lampu secara otomatis.
\end{abstract}

Kata Kunci :Metode Rational Unified Proces, Arduino, Unified Modeling Language, Fuzzy Logic, pengontrolan dan monitoring lampu.

Abstract - The rapid development of technology in various field, including the field of electronic, necessity of facility and comfort in controlling the electric devices are important, especially in controlling and monitoring the lamps. Nowdays society can control the electrical devices only with the switch connected by cabel. Then, it is needed a control system and monitoring lamps automatically. One of the systems is using micro controller. Based on the problems identified in Computer Sciences Faculty, system for controlling and monitoring lamps hasn't run efectivelly because it still uses manual and it has not got the lamps should be burn. Method of software development used in this research is Rational Unified Process (RUP) method by using design of Unified Modeling Language (UML) such as using case diagram, scenario, activity diagram, class diagram dan sequence diagram. Meanwhile, the problem solving method is using Fuzzy Logic method. System of controlling and monitoring the lamps built by fuzzy logic method is efective automaticallty. The system can be applied to the research object and assist in the process of controlling and monitoring the lamp automatically.

Keyword : Rational Unified Proces method, Arduino, Unified Modeling Language,Fuzzy Logic, Controlling and Monitoring the Lamps.

\section{PENDAHULUAN}

\subsection{Latar Belakang}

Seiring kemajuan teknologi yang semakin pesat diberbagai bidang, termasuk bidang elektronika kebutuhan akan kemudahan dan kenyamanan dalam pengontrolan alat-alat listrik sangat penting, khusunya pengontrolan dan monitoring lampu. Selama ini masyarakat dapat mengontrol perangkat listrik hanya dengan saklar yang terhubung melalui kabel, akan tetapi pengontrolan tersebut dibatasi oleh jarak jangkauan. Contohnya pada koridor di Fakultas Ilmu Komputer Universitas Kuningan. 
Di koridor Fakultas Ilmu Komputer lampu yang terpasang sepanjang koridor proses menyalakan dan mematikan masih dilakukan secara manual, termasuk dalam pengontrolan dan monitoring lampunya. Sehingga terkadang petugas lupa untuk menyalakan dan mematikan lampu. Hal ini dampaknya konsumsi daya listrik menjadi tidak teratur dan menyebabkan biaya listriknya menjadi besar.

Maka dari itu dibutuhkan suatu sistem kontrol dan monitoring lampu secara otomatis, salah satu sistem yang dibuat yaitu dengan menggunakan mikrokontroller. Arduino merupakan pengendali mikro single-board yang bersifat open-source, diturunkan dari Wiring platform, dirancang untuk memudahkan penggunaan elektronik dalam berbagai bidang.

Arduino dapat dimanfaatkan sebagai pengontrol lampu yang dipadukan dengan modul-modul tertentu seperti relay dan lain-lain. Arduino juga dapat terintegrasi dengan perangkat elektronik lain seperti smartphone melalui jaringan yang terhubung dengan arduino dan smartphone itu sendiri.

\subsection{Rumusan Masalah}

Maka dapat dirumuskan masalah sebagai berikut :

1) Bagaimana membuat sistem pengontrolan dan monitoring lampu berbasis mikrokontroller yang terintegrasi dengan smartphone?

2) Bagaimana membangun sebuah aplikasi pengontrolan dan monitoring lampu otomatis berbasis android yang dapat membantu memudahkan dalam pengontrolan lampu ?

3) Bagaimana cara menerapkan metode Fuzzy Logic pada sistem pengontrolan dan monitoring lampu?

\subsection{Batasan Masalah}

p-ISSN : 1858-3911, e-ISSN : 2614-5405

https://journal.uniku.ac.id/index.php/ilkom

Batasan Masalah dari penelitian ini adalah:

1) Sistem dirancang untuk mengontrol dan memonitoring lampu di Koridor lantai 1 dan 2 Fakultas Ilmu Komputer Universitas Kuningan.

2) Perancangan sistem pengontrolan dan monitoring menggunakan Arduino Uno dan sensor LDR.

3) Sensor LDR sebagai otomatisasi lampu sesuai intensitas cahaya dari keanggotaan fuzzy logic.

4) Aplikasi yang akan dibangun menggunakan bahasa pemograman $\mathrm{C}$ pada arduino IDE dan bahasa pemograman java pada android studio 3.0.1.

5) Aplikasi yang dibangun menggunakan android versi 4.2.2 (JellyBean) API 17 dengan android studio sebagai editor.

6) Aplikasi yang dibangun berfungsi untuk pengontrolan dan monitoring lampu di setiap koridor.

7) Notifikasi pada aplikasi yang dibangun, jika lampu menyala warna biru, jika lampu tidak menyala warna merah.

8) Konektivitas antara sistem dengan aplikasi menggunakan modul WIFI (esp 8266).

\subsection{Tujuan Penelitian}

Tujuan dari penelitian ini adalah:

1) Merancang sistem pengontrolan dan monitoring lampu secara otomatis berbasis arduino.

2) Menerapkan sensor LDR sebagai input sistem pengendali lampu sesuai intensitas cahaya.

3) Merancang aplikasi berbasis android untuk pengontrolan lampu yang dapat digunakan secara online.

\section{METODOLOGI PENELITIAN}

Rational Unfied Process (RUP) merupakan metode pengembangan yang berorientasi pada proses pendekatan berulang-ulang (iterative), hal ini memungkinkan penulis untuk menemukan kesalahan sedini mungkin, yang secara 
radikal mengurangi biaya memperbaiki kesalahan, fokus pada arsitektur (architecture-centric), lebih diarahkan berdasarkan penggunaan kasus (use case driven). RUP merupakan rekayasa perangkat lunak dengan pendefinisian yang baik (well defined) dan penstrukturan yang baik (well structured). (Rosa A.S, M. Shalahuddin. 2013) [1]

Proses pengulangan/iterative pada RUP secara global dapat dilihat pada gambar berikut:

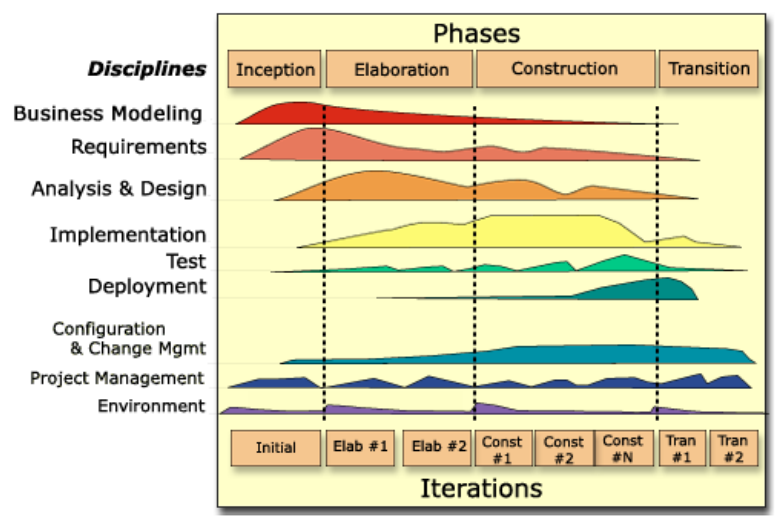

Gambar 1. Rational Unified Procces (RUP)

(Sumber : Rosa A.S, M. Shalahuddin. 2013)

\subsection{Mikrokontroler}

Menurut Dian Artanto (2008) dalam bukunya "Mikrokontroller merupakan sistem komputer yang seluruh atau sebagian besar elemennya dikemas dalam satu chip IC sehingga sering juga disebut single chip microcomputer".

\subsubsection{Mikrokontroler Arduino}

"Arduino adalah sebuah pengendali micro board tunggal yang memiliki sifat terbuka (open source) yang diturunkan dari platform berbasis wiring" (Feri Djuandi,2011: 2).[4]

\subsection{Arduino Mega}

\subsubsection{Arduino Uno ATMega 328}

Arduino Uno berukuran sebesar kartu kredit. Walaupun berukuran kecil
p-ISSN : 1858-3911, e-ISSN : 2614-5405

https://journal.uniku.ac.id/index.php/ilkom

seperti itu, papan mengandung mikrokontroler dan sejumlah input/output (I/O) yang memudahkan pemakaian untuk menciptakan berbagai proyek elektronika yang dikhususkan untuk menangani tujuan tertentu. Bagian-bagian di Arduino Uno yang perlu diketahui terlebih dahulu ditujukan di Gambar 3.1.

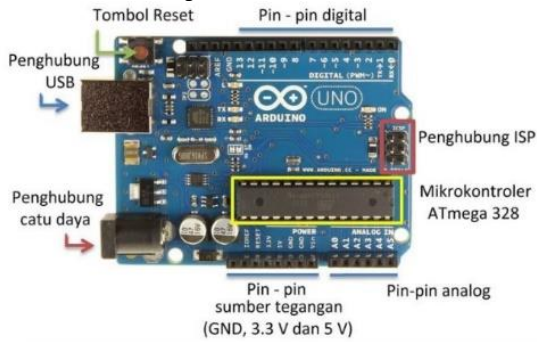

Gambar 2. Penjelasan beberapa bagian di Arduino Uno (Abdul Kadir, 2016)[5]

\subsection{Pengertian Sensor}

Sensor dan transducer merupakan peralatan atau komponen yang mempunyai peranan penting dalam sebuah sistem pengaturan otomatis. Ketepatan dan kesesuaian dalam memilih sensor akan sangat menentukan kinerja dari sistem pengaturan secara otomatis. Secara umum berdasarkan fungsi dan penggunaannya sensor dapat dikelompokan menjadi 3 bagian yaitu :

a. Sensor thermal (panas)

b. Sensor mekanis

c. Sensor optic (cahaya)

\subsection{Metode Fuzzy Logic}

Logika fuzzy memiliki beberapa komponen yang harus dipahami seperti himpunan fuzzy, fungsi keanggotaan, operator pada himpunan fuzzy, inferensi fuzzy dan defuzzifikasi. Berikut adalah gambar skema dasar dari Fuzzy logic : 


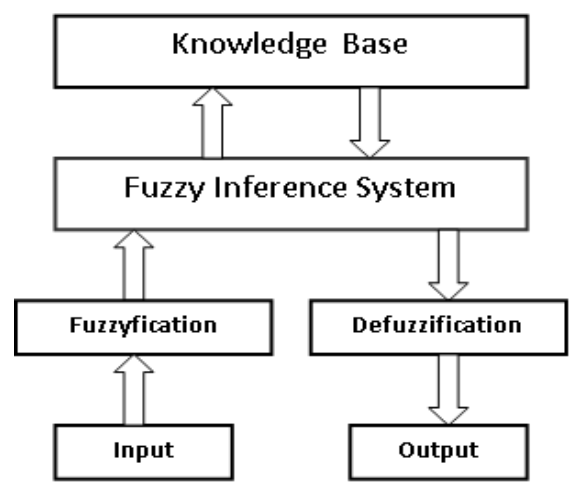

Gambar 3. Skema Dasar Metode Fuzzy

(Sumber : Rinaldi Munir 2007)[6]

Berikut adalah penjelasan dari skema metode fuzzy :

1. Input fuzzy berupa bilangan crisp (tegas) yang dinyatakan dalam himpunan input.

2. Fuzzifikasi merupakan proses untuk mengubah bilangan crisp menjadi nilai keanggotaan dalam himpunan fuzzy.

3. Fuzzy inference system merupakan bagian pengambilan kesimpulan (reasoning) dan keputusan.

4. Knowledge base berisi aturan-aturan yang biasanya dinyatakan dengan perintah IF .... THEN....

5. Defuzzification merupakan proses untuk merubah nilai output fuzzy menjadi nilai crisp.

Contoh berikut akan menjelaskan bagaimana konsep kerja sensor LDR sesuai "Intensitas Cahaya" yang digolongkan "gelap", "redup", "terang", "terang sekali" dalam pengertian fuzzy/samar dan crisp (tegas). Misalnya diberikan suatu definisi bahwa setiap nilai $0>250$ dikatakan "gelap", nilai 251>400 dikatakan "redup", nilai 401>600 "terang" dan jika nilai >950 "sangat terang".

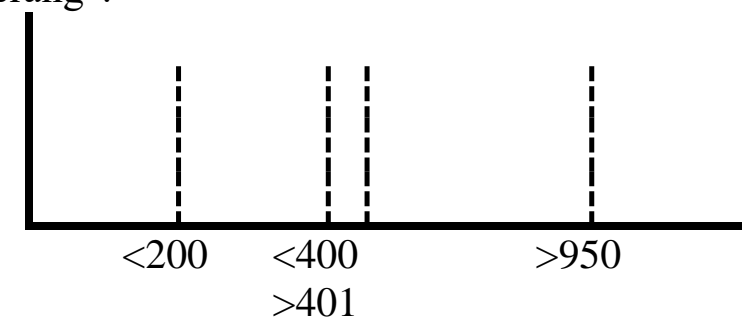

p-ISSN : 1858-3911, e-ISSN : 2614-5405

https://journal.uniku.ac.id/index.php/ilkom

Dalam pengertian crisp (tegas), batasbatas antara "gelap" nilai cahaya (0), "gelap", "redup", "terang" dan "terang sekali", setiap nilai cahaya $(0, \ldots, 250)$ adalah "gelap", nilai cahaya $(251, \ldots, 400)$ "redup", dan nilai $(401, \ldots, 600)$ "terang", "terang sekali".

\section{HASIL DAN PEMBAHASAN}

\subsection{Analisis Sistem}

Analisis sistem merupakan tahap yang bertujuan untuk memahami sistem, mengetahui kekurangan sistem, dan menentukan kebutuhan sistem.

\subsection{Analisis Kebutuhan Fungsional}

Analisis kebutuhan fungsional disini adalah langkah-langkah atau tahapan yang dilakukan oleh sistem.

1. Proses penerimaan perintah yang dikirim langsung oleh perangkat yang terhubung. Proses ini berada pada kondisi jika pengguna ingin menyalakan lampu secara manual melalui perangkat smartphone.

2. Proses pembacaan kondisi lingkungan dan waktu. Proses ini dimulai ketika pengguna menyalakan sistem otomatis untuk pembacaan kondisi cahaya sekitar sensor yang terpasang.

3. Metode yang digunakan fuzzy logic sesuai intensitas cahaya. Proses ini merupakan tahapan dari hasil pembacaan kondisi dan waktu serta diproses menggunakan algoritma fuzzy logic yang digunakan untuk mengontrol relay dalam menyalakan dan mematikan lampu.

\subsection{Metode Penyelesaian Masalah}

Dalam penelitian ini metode penyelesaian masalah yang diterapkan adalah fuzzy logic. Tahap penerapan fuzzy logic pada penelitian ini, yaitu dengan mengambil nilai dari sensor cahaya yang menghasilkan nilai sensitifitas cahaya yang menjadi input dari proses fuzzy logic. 
Langkah dari proses fuzzification adalah mengkonversi masukanmasukan nilai kebenaran dari perangkat sensor menjadi bentuk nilai linguistik atau fuzzy input.

Fungsi keanggotaan sensor cahaya dapat dilihat pada gambar 4.1.

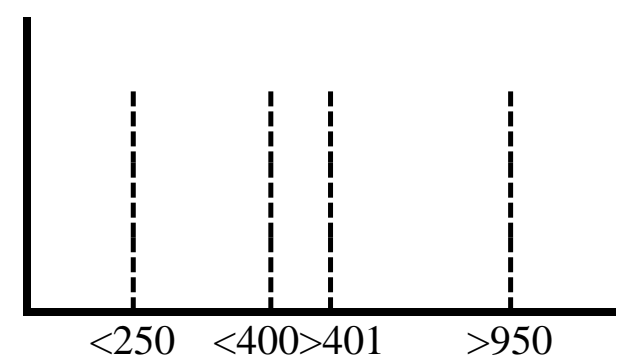

Gambar 4. Fungsi Keanggotaan Sensor Cahaya

Keterangan :

Tabel 1. Keterangan Fungsi Keanggotaan Sensor Cahaya

\begin{tabular}{|c|c|}
\hline $\begin{array}{c}\text { Nilai Crips } \\
\text { (Sensor } \\
\text { Cahaya) }\end{array}$ & $\begin{array}{c}\text { Nilai Linguistik } \\
\text { (fuzzy input) }\end{array}$ \\
\hline$<250$ & Gelap \\
\hline$<400$ & Redup \\
\hline$>401$ & Terang \\
\hline$>950$ & Terang Sekali \\
\hline
\end{tabular}

\subsubsection{Inference}

Berdasarkan proses fuzzification sensor yang ada, akan dibuat aturan dari nilainilai yang terbaca dari sensor tersebut. Dimana aturan disini merupakan perintah untuk menyalakan atau mematikan lampu. Adapun aturan-aturannya sebagai berikut:

Tabel 4.2 Rule Inference Aturan Fuzzy

\begin{tabular}{|c|l|l|l|l|}
\hline & & & & \\
\hline
\end{tabular}

Keterangan
p-ISSN : 1858-3911, e-ISSN : 2614-5405

https://journal.uniku.ac.id/index.php/ilkom

$\begin{array}{llll}\text { LKN } & = & \text { Lampu } & \text { Koridor } \\ \text { Nyala } & & & \\ \text { LKM } & = & \text { Lampu } & \text { Koridor } \\ \text { Mati } & & \\ >950 & = & \text { Terang Sekali } \\ >401 & = & \text { Terang } & \\ <400 & = & \text { Redup } & \\ <250 & = & \text { Gelap } & \\ \mathrm{P} & = & \text { Pagi } & \\ \text { Si } & = & \text { Siang } \\ \text { So } & = & \text { Sore } \\ \text { M } & = & \text { Malam }\end{array}$

Dari uraian aturan fuzzy / rule inference yang berasal dari 4 kolom sensor cahaya dan 4 kolom waktu maka menghasilkan 16 aturan. Hasil dari aturan tersebut adalah sebagai berikut:

1) IF $\mathrm{SC}=>600$ AND WAKTU $=\mathrm{P}$ THEN LKM

2) $\mathrm{IF} \mathrm{SC}=>600 \mathrm{AND} \mathrm{WAKTU}=\mathrm{Si}$ THEN LKM

3) IF $\mathrm{SC}=>600$ AND WAKTU $=$ So THEN LKM

4) IF $\mathrm{SC}=>600$ AND WAKTU $=\mathrm{M}$ THEN LKN

5) IF $\mathrm{SC}=>400$ AND WAKTU $=\mathrm{P}$ THEN LKM

6) IF $\mathrm{SC}=>400$ AND WAKTU $=\mathrm{Si}$ THEN LKM

7) IF $\mathrm{SC}=>400$ AND WAKTU $=$ So THEN LKM

8) IF $\mathrm{SC}=>400$ AND WAKTU $=\mathrm{M}$ THEN LKN

9) IF $\mathrm{SC}=<400$ AND WAKTU $=\mathrm{P}$ THEN LKM

10) $\mathrm{IF} \mathrm{SC}=<400$ AND WAKTU $=\mathrm{Si}$ THEN LKM

11) $\mathrm{IF}$ SC $=<400$ AND WAKTU $=$ So THEN LKN

12) $\mathrm{IF} \mathrm{SC}=<400$ AND WAKTU $=\mathrm{M}$ THEN LKN

13) $\mathrm{IF} \mathrm{SC}=<250$ AND WAKTU $=\mathrm{P}$ THEN LKN

14) $\mathrm{IF} \mathrm{SC}=<250$ AND WAKTU $=\mathrm{Si}$ THEN LKN

15) $\mathrm{IF}$ SC $=<250$ AND WAKTU $=$ So THEN LKN

16) $\mathrm{IF}$ SC $=<250$ AND WAKTU $=\mathrm{M}$ THEN LKN 


\subsubsection{Defuzzification}

Proses defuzzification disini akan mengubah aturan fuzzy atau rule inference menjadi nilai crips output yang digunakan sebagai pengontrolan lampu pada setiap koridor.

1. LKN :Lampu Koridor Nyala Lampu Koridor =PIN $\quad 1-8$ (HIGH)

2. LKM :Lampu Koridor Mati Lampu Koridor =PIN $\quad 1-8$ (LOW)

\subsection{Use Case Diagram}

Diagram use case merupakan diagram yang memodelkan aspek perilaku sistem. Masing-masing diagram use case memiliki aktor, use case, dan hubungannya.

Pada sistem kontrol dan monitoring ini dibagi menjadi satu aktor yaitu sebagai petugas pelaksana yang merupakan pengguna yang sudah terdaftar didalam sistem yang memiliki hak akses secara penuh untuk mengontrol dan monitoring lampu.

Berikut Use Case Diagram yang diusulkan untuk aplikasi kontrol dan monitoring lampu. Ditunjukan pada gambar

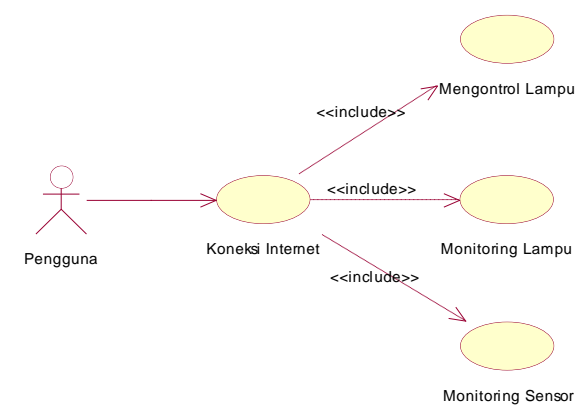

Gambar 5. Use Case Diagram

\subsection{Activity Diagram}

Activity diagram menggambarkan berbagai alir aktivitas dalam sistem yang sedang dirancang, bagaimana masingmasing alir berawal, decision yang mungkin terjadi, dan bagaimana mereka berakhir. Berikut merupakan diagram aktivitas dari sistem kontrol dan monitoring lampu:
p-ISSN : 1858-3911, e-ISSN : 2614-5405

https://journal.uniku.ac.id/index.php/ilkom

1. Activity Diagram Koneksi Internet

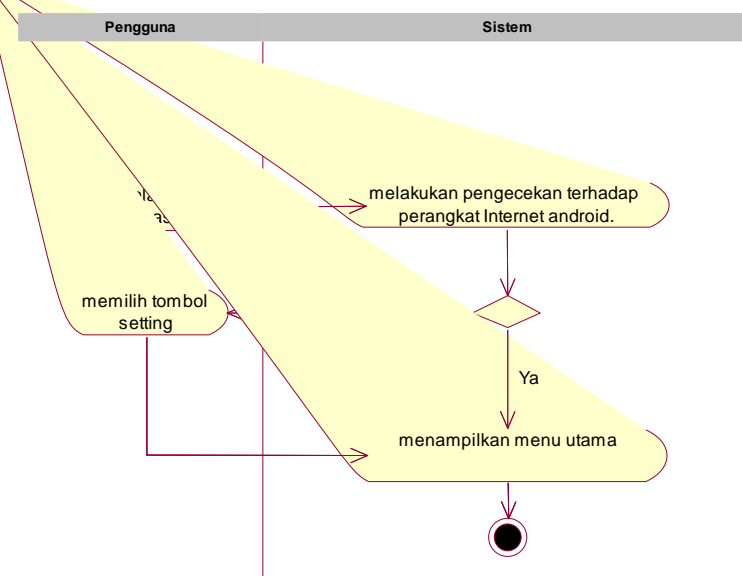

Gambar 6. Activity Diagram Koneksi Internet

2. Activity Diagram Mengontrol Lampu

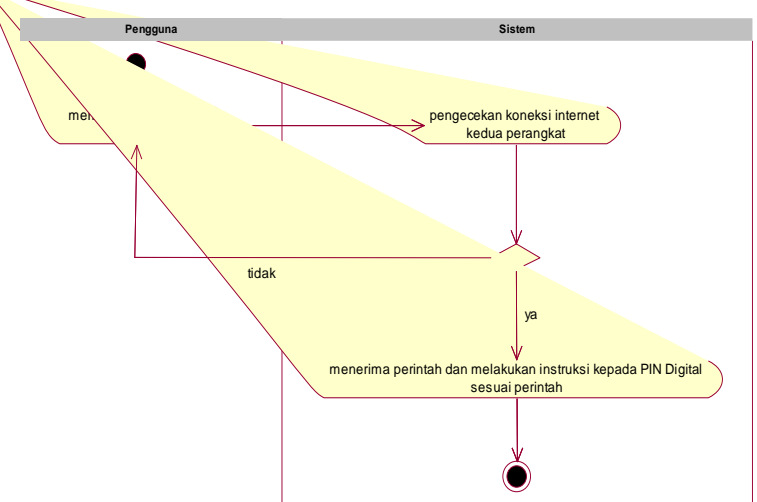

Gambar 7. Activity Diagram Mengontrol Lampu

3. Activity Diagram Monitoring Sensor

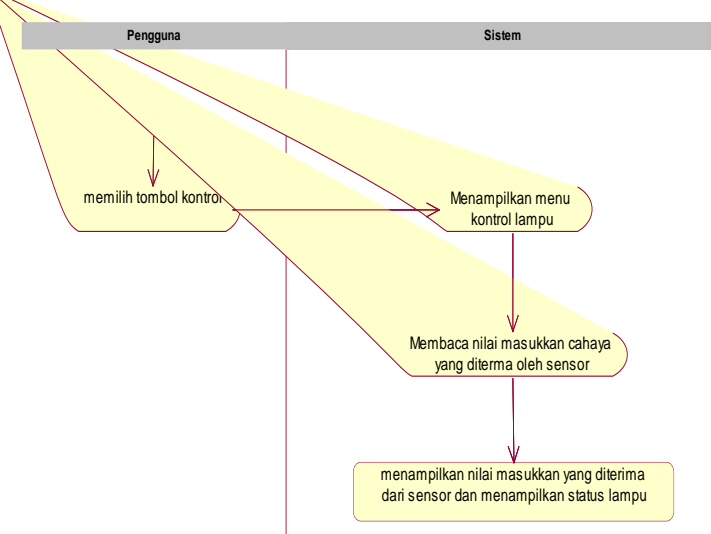

Gambar 8. Activity Diagram Monitoring Sensor 


\subsection{Sequence Diagram}

Berikut ini merupakan sequence diagram yang menggambarkan interaksi antar objek dalam sistem:

1. Sequence Diagram Koneksi Internet

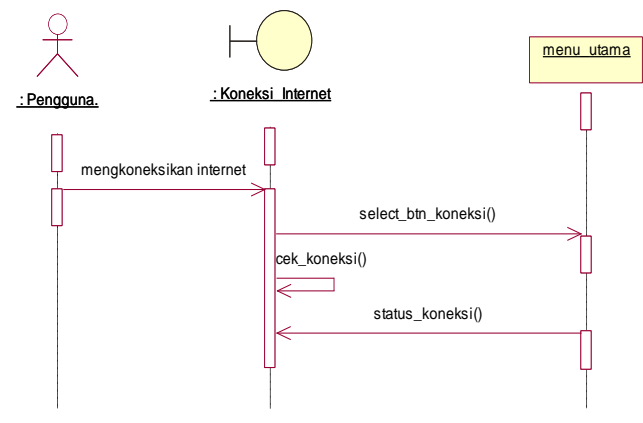

Gambar 9. Sequence Diagram Koneksi Internet

2. Sequence Diagram Pengontrolan

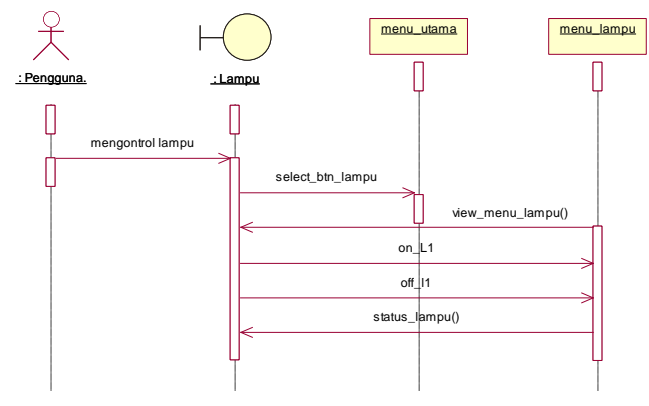

Gambar 10. Sequence Diagram Pengontrolan

3. Sequence Diagram Monitoring Lampu

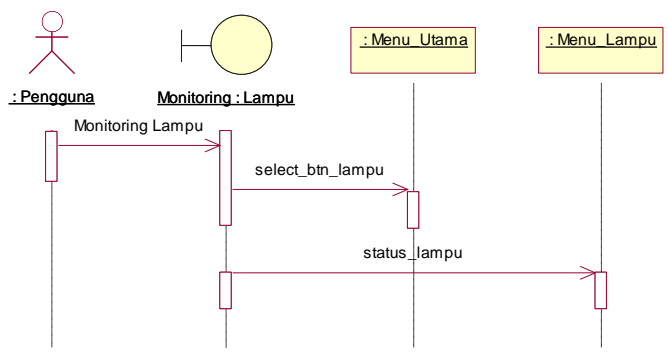

Gambar 11. Sequence Diagram Monitoring Lampu

Pada tahap ini pengujian sistem yang dibahas berdasarkan objek yang akan diuji berupa form-form sebagai berikut:

1. Form Splash Screen

Pengguna akan dihadapkan pada tampilan awal yaitu form splash
p-ISSN : 1858-3911, e-ISSN : 2614-5405

https://journal.uniku.ac.id/index.php/ilkom

screen yang bertahan selama 3 detik yang berlanjut ke form menu utama.

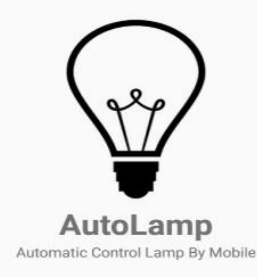

Gambar 12. Tampilan Splash Screen

2. Menu Utama

Pada form menu utama ini memiliki beberapa item yaitu Kontrol Lampu, Bantuan, Tentang dan Keluar.

Tampilan menu utama dapat dilihat pada gambar 5.2 berikut.

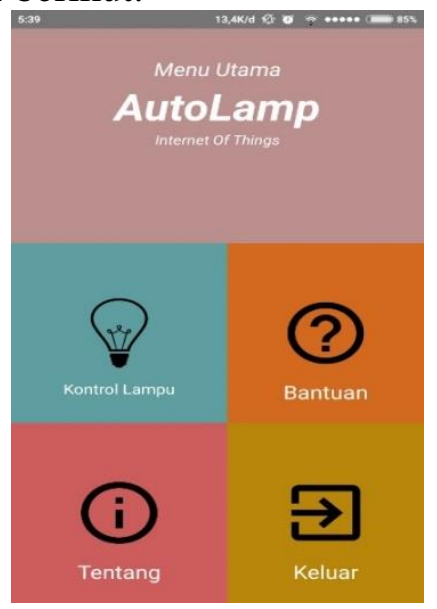

Gambar 13. Tampilan Menu Utama

\section{Form Kontrol}

Pada form ini pengguna dapat menyalakan atau mematikan lampu satu persatu maupun semua lampu setiap lantai, dan dapat menyalakan secara otomatis sesuai intensitas cahaya dengan merubah ke mode sensor. Pada setiap perintah yang dipilih akan memunculkan notifikasi "berhasil !!!". Untuk tampilan monitoring dapat dilihat pada gambar 5.3 berikut. 
JURNAL NUANSA INFORMATIKA

Volume 12 Nomor 1, Januari 2018

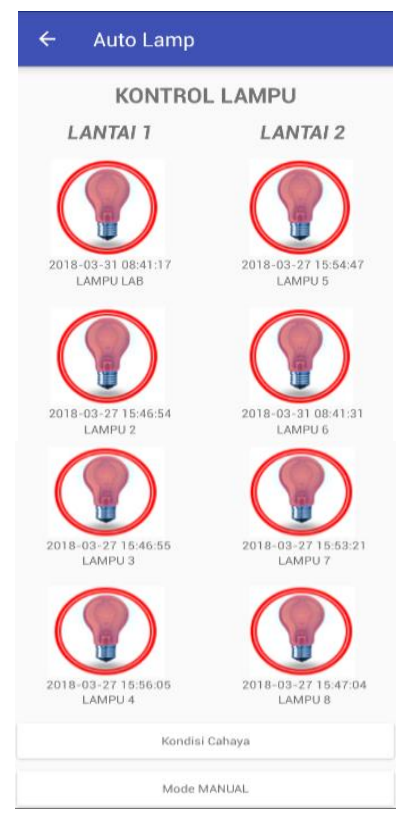

Gambar 14. Tampilan Menu Lampu Pada Saat lampu mati

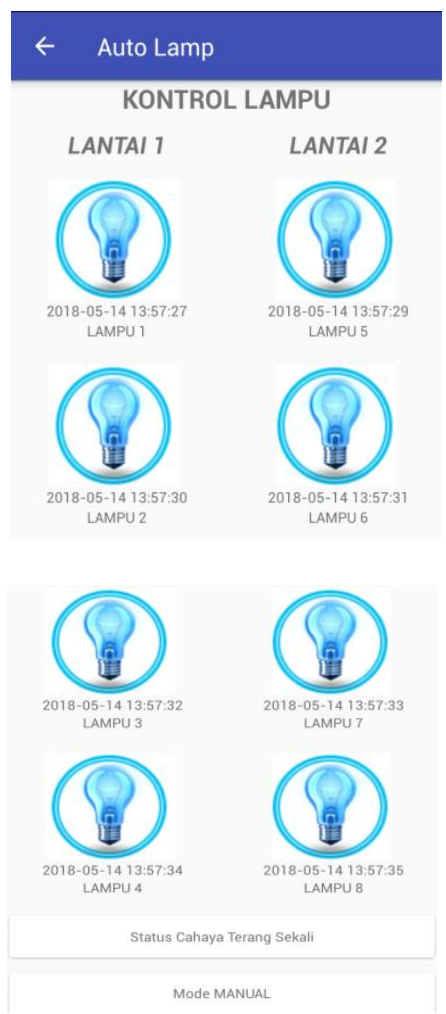

Gambar 15. Tampilan Menu Lampu Pada Saat Lampu Menyala

4. FormPetunjuk

Pengguna akan diperlihatkan aturan penggunaan aplikasi.
p-ISSN : 1858-3911, e-ISSN : 2614-5405

https://journal.uniku.ac.id/index.php/ilkom

Untuk tampilan laporan dapat dilihat pada gambar berikut.

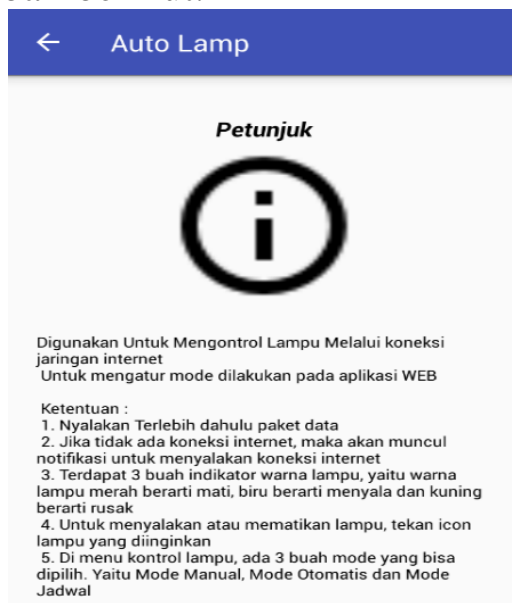

Gambar 16. Tampilan Petunjuk

\section{Maket Gedung Fakutas Ilmu Komputer}

Perancangan sebuah model yang sudah melakukan penelitian pada sebuah gedung fakultas ilmu komputer, yang terdiri dari 2 lantai dan memiliki 8 buah lampu. Seperti gambar dibawah ini.

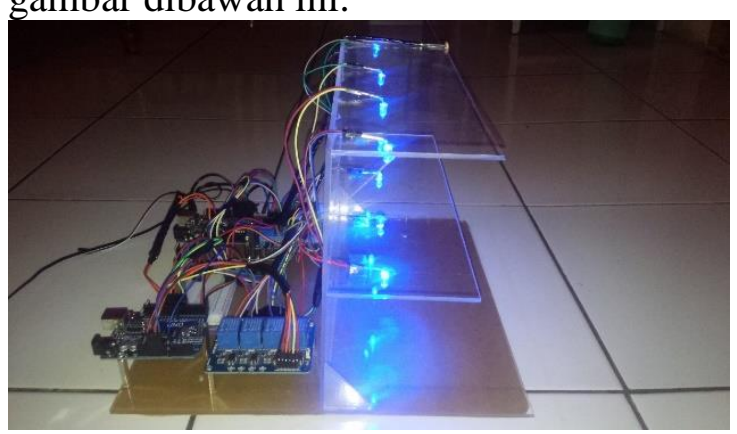

Gambar 17. Tampilan Maket

\section{KESIMPULAN}

Berdasarkan hasil penelitian yang telah dilakukan yaitu, maka penulis mengambil beberapa kesimpulan sebagai berikut.

1. Aplikasi AutoLamp berbasis android ini sebagai kontrol dan monitoring lampu secara manual / otomatis.

2. Sensor LDR pada aplikasi ini sebagai input sistem pengendali lampu sesuai intensitas cahaya.

3. Pada aplikasi pengontrolan dan monitoring lampu ini menggunakan jaringan internet dan tidak terbatas oleh jarak dalam hal pengontrolannya. 


\section{SARAN}

Adapun saran-saran yang dapat diberikan untuk pengembangan / penelitian selanjutnya yaitu :

1. Aplikasi pengontrolan lampu ini dapat dikembangkan untuk skala yang lebih besar dan kondisi real.

2. Perlu ditambahkan fitur yang dapat mendeteksi kondisi lampu, apakah lampu tersebut berfungsi atau tidak (menyala / mati).

3. Diharapkan aplikasi ini memiliki fitur yang dapat mengetahui besarnya beban dan biaya pengguna listrik.

\section{DAFTAR PUSTAKA}

[1] A.S, Rosa dan M. Salahuddin. 2013. Rekayasa Perangkat Lunak Terstruktur dan Berorientasi Objek. Bandung : Informatika Bandung

[2] Pressman, Roger S. 2012. Rekayasa Perangkat Lunak . Yogyakarta: Andi

[3] Sutabri, Tata. (2012). Analisis Sistem Informasi. Yogyakarta : Andi.

[4] Djuandi, Feri. 2011. Pengenalan Arduino.Tersedia www.tobuku.com/docs/ ArduinoPengenalan.pdf. Diakses 5 April 2017.

[5] Kadir, Abdul. 2003. Perancangan Sistem Informasi. Yogyakarta : Andi

[6] Munir, Rinaldi. (2007). "Pengantar Logika Fuzzy". Teknik Informatika STEI ITB. 